Article

\title{
Moringa oleifera Hot Water Extract Protects Vero Cells from Hydrogen Peroxide-Induced Oxidative Stress by Regulating Mitochondria-Mediated Apoptotic Pathway and Nrf2/HO-1 Signaling
}

\author{
Kirinde Gedara Isuru Sandanuwan Kirindage ${ }^{1}$ (D) Ilekuttige Priyan Shanura Fernando ${ }^{2} \mathbb{D}$, \\ Arachchige Maheshika Kumari Jayasinghe 1(D), Eui-Jeong Han 1,3 (D, \\ Mawalle Kankanamge Hasitha Madhawa Dias ${ }^{1}{ }^{(D)}$, Kyung-Pil Kang ${ }^{4}$, Sung-Ig Moon ${ }^{4}$, Tai-Sun Shin ${ }^{5}$, \\ Ayeong Ma ${ }^{5}$ and Ginnae Ahn ${ }^{1,2, *(D)}$
}

check for updates

Citation: Kirindage, K.G.I.S.; Fernando, I.P.S.; Jayasinghe, A.M.K.; Han, E.-J.; Dias, M.K.H.M.;

Kang, K.-P.; Moon, S.-I.; Shin, T.-S.; Ma, A.; Ahn, G. Moringa oleifera Hot Water Extract Protects Vero Cells from Hydrogen Peroxide-Induced Oxidative Stress by Regulating Mitochondria-Mediated Apoptotic Pathway and Nrf2/HO-1 Signaling. Foods 2022, 11, 420. https://doi.org/ $10.3390 /$ foods 11030420

Academic Editor: Ioannis Mourtzinos

Received: 16 December 2021

Accepted: 27 January 2022

Published: 31 January 2022

Publisher's Note: MDPI stays neutral with regard to jurisdictional claims in published maps and institutional affiliations.

Copyright: (C) 2022 by the authors. Licensee MDPI, Basel, Switzerland. This article is an open access article distributed under the terms and conditions of the Creative Commons Attribution (CC BY) license (https:// creativecommons.org/licenses/by/ $4.0 /)$.
1 Department of Food Technology and Nutrition, Chonnam National University, Yeosu 59626, Korea; 218388@jnu.ac.kr (K.G.I.S.K.); 218385@jnu.ac.kr (A.M.K.J.); iosu5772@naver.com (E.-J.H.); 198807@jnu.ac.kr (M.K.H.M.D.)

2 Department of Marine Bio-Food Sciences, Chonnam National University, Yeosu 59626, Korea; shanurabru@gmail.com

3 Research Center for Healthcare and Biomedical Engineering, Chonnam National University, Yeosu 59626, Korea

4 Jeju Changhae Fisheries Co., Ltd., Jeju 63072, Korea; golf87@naver.com (K.-P.K.); jejuchanghae@naver.com (S.-I.M.)

5 Department of Food Science and Nutrition, Chonnam National University, 77 Yongbong-ro, Buk-gu, Gwangju 61186, Korea; shints@chonnam.ac.kr (T.-S.S.); ayeong_ma@daum.net (A.M.)

* Correspondence: gnahn@chonnam.ac.kr; Tel.: +82-61-659-7213

\begin{abstract}
The present study discloses the identification of phenolic compounds in Moringa oleifera hot water extract $(\mathrm{MOH})$ and the evaluation of its antioxidant activity on $\mathrm{H}_{2} \mathrm{O}_{2}$-induced oxidative stress in Vero cells. Upon analysis, $\mathrm{MOH}$ was found to contain phenolic compounds and indicated 2,2-diphenyl-1-picrylhydrazyl (DPPH) and 2,2-azino-bis (3-ethylbenzothiazoline-6-sulfonic acid) diammonium salt $\left(\mathrm{ABTS}^{+}\right.$) radical scavenging with $\mathrm{IC}_{50}$ values of 102.52 and $122.55 \mu \mathrm{g} / \mathrm{mL}$, respectively. The ferric reducing antioxidant power (FRAP) of $\mathrm{MOH}$ indicated a dose-dependent increase with a maximum absorbance at $125 \mu \mathrm{g} / \mathrm{mL}$ and the oxygen radical absorbance capacity (ORAC) of $\mathrm{MOH}$ was $1004.95 \mu \mathrm{mol} \mathrm{TE} / \mathrm{mg}$. Results showed that $\mathrm{MOH}$ dose-dependently reduced intracellular ROS generation in $\mathrm{H}_{2} \mathrm{O}_{2}$-stimulated Vero cells while increasing the cell viability. Fluorescence microscopy and flowcytometric analyses have supported the above findings. $\mathrm{MOH}$ markedly suppressed the $\mathrm{H}_{2} \mathrm{O}_{2}$-induced mitochondrial depolarization and apoptosis through suppression of the mitochondrial-mediated apoptosis pathway and activated the Nrf2/HO-1 signaling pathway by possibly involving $\mathrm{H}_{2} \mathrm{O}_{2}$ generation in cell media. Findings of western blot were supported by immunocytochemistry of Nrf2 nuclear translocation. Thus, $\mathrm{MOH}$ bioactivity would potentiate its applications in manufacturing functional food.
\end{abstract}

Keywords: Moringa oleifera; oxidative stress; antioxidants; Vero; polyphenols

\section{Introduction}

Exposure to ionizing radiation, xenobiotics, and disease conditions generate oxidative stress in live cells, which has been linked to the pathogenesis of a variety of detrimental cellular responses [1]. As evidence accumulated over time has shown, oxidative and inflammatory processes in the human body are triggered by lifestyle-related factors such as exposure to contaminated air, smoke and alcohol consumption, exposure to ionization radiation, xenobiotics, and urbanization hypoxia [2]. Cell and tissue damage, and, hence, 
the development of non-communicable diseases, are primarily caused by oxidative stress and chronic inflammatory processes [2]. The dysregulated production of reactive oxygen species (ROS) in cells is a well-known reason for oxidative stress and oxidative stress in cells is exacerbated when oxidation reactions are prevalent in the organism [3].

The cellular enzymatic and non-enzymatic oxidant and antioxidant systems play a pivotal role in neutralizing superoxide anion radicals, hydrogen peroxide, and hydroxyl radicals, as well as secondary reactive species such as peroxyl and alkoxyl radicals generated by subsequent oxidation in live cells. Superoxide dismutase converts anion radicals, which are generated by a series of enzymes, into intracellular hydrogen peroxide in the cell environment. Moreover, hydrogen peroxide in cells can be produced by enzymes such as nicotine adenine dinucleotide phosphate oxidase, xanthine oxidase, and amino acid oxidase, as well as increased oxygen consumption in metabolic processes in the peroxisome [4] Even so, cells are equipped with an antioxidant defense system such as peroxiredoxins and glutathione peroxidases, which catalyzes the removal of $\mathrm{H}_{2} \mathrm{O}_{2}$ to maintain their levels at physiological concentration [5]. If this is unable to convert hydrogen peroxide to water and oxygen, then hydrogen peroxide can react with superoxide radicals or undergo Fenton reactions or Haber-Weiss reactions to generate hydroxyl radicals, which can wreak havoc on cells by causing oxidative stress [4]. Apart from that, the mitochondrial electron transport system acts as a primary endogenous ROS generation site in live cells. Moreover, chemicals such as $\mathrm{H}_{2} \mathrm{O}_{2}$ may readily diffuse across the cell membrane, react with intracellular ions, and cause intracellular damage [6]. ROS is linked to a variety of complications, including cancer, heart disease, neurological illnesses, and infertility, due to its potential to damage nucleic acid, protein alterations, and lipid peroxidation $[7,8]$. When it comes to the liver, a disturbed balance of pro and antioxidants has been found as a risk factor for liver cancer progression [9]. Moreover, ROS causes the pathogenesis of acute kidney injury and its transition to chronic kidney disease [10-12]. Hence, research into naturally occurring antioxidants for the prevention of oxidative stress and related health disorders has received a lot of attention in recent years [13]. The strong antioxidants with low toxicity are potentially beneficial for humans as supplementary antioxidants for remediating the effect of accumulated ROS in cells [6]. Aside from that, natural alternatives to synthetic flavor enhancers and antioxidants in the food business are becoming increasingly popular to prevent oxidation and preserve sensory qualities [14].

A wide range of antioxidants in food and medicinal plants have been identified over the decades and they can be split into two groups based on their polarity as 'water-soluble' and 'fat-soluble' antioxidants. Phenols, flavonoids, anthocyanins, stilbenes, and ligands are water-soluble antioxidants, while $\alpha$-carotene, $\beta$-carotene, lycopene, lutein, and zeaxanthin are lipo-soluble antioxidants found primarily in plants [15]. The dietary phytonutrients, including Moringa oleifera flavonoids, were of major interest in the study because of their nutritional properties, potential anti-inflammatory and antioxidant properties, and their aptitude to prevent normal cell DNA damage and to encourage cancer cell death as a therapeutic input [16].

M. oleifera, generally known as 'Moringa', is one of the well-known sources of biocompatible antioxidants that abundantly grow in semiarid, tropical, and subtropical areas [17]. Cooked drumsticks are known to be popular in many countries including South Asia and some African countries; however, leaves are not popular as a food commodity widely. As well as this, M. oleifera is a prevalent ingredient in traditional medicine in many countries, where it has promised effects on various chronic diseases [18]. Numerous research have confirmed the presence of phenolic compounds such as anthocyanins and flavonoids in $M$. oleifera leaves, which are responsible for its strong antioxidant free radical scavenging and antidiabetic activities $[17,19]$. According to the present understanding, $M$. oleifera can be used as a treatment for a variety of conditions related to heart disease, diabetes, cancer, and fatty liver [20]. The effect of M. oleifera hot water extract on major organs has previously been investigated using rat models to measure lipid peroxide levels [21]. However, certain gaps in understanding may be filled by taking on further studies on Moringa. 
As oxidative stress has implications for human kidneys, Vero cells derived from African green monkey kidney fibroblasts were used in assessing oxidative stress using $\mathrm{H}_{2} \mathrm{O}_{2}$ to generate ROS in cells [22]. The present study was carried out to evaluate the efficacy of the hot water extraction method to extract $M$. oleifera and evaluate the antioxidant activity of $M$. oleifera hot water extract $(\mathrm{MOH})$ on $\mathrm{H}_{2} \mathrm{O}_{2}$-induced oxidative stress in Vero cells. The study was carried out by hypothesizing that $\mathrm{MOH}$ ameliorates the effects of $\mathrm{H}_{2} \mathrm{O}_{2}$-induced oxidative stress in Vero cells by suppressing the mitochondria-mediated apoptosis pathway and promoting the $\mathrm{Nrf2/HO}-1$ signaling pathway.

\section{Materials and Methods}

\subsection{Materials}

M. oleifera was collected from Suncheon Bay Moringa Cooperative (Suncheon-si, Jeollanam-do, Korea). Dulbecco's modified eagle medium (DMEM), and a mixture of streptomycin and penicillin (P/S) as antibiotics were purchased from GibcoBRL (Grand Island, NY, USA). Fetal bovine serum (FBS) was purchased from Welgene (Gyeongsangbuk-do, South Korea). 2,2-azino-bis(3-ethylbenzothiazoline-6-sulfonic acid) diammonium salt (ABTS), 2,2-diphenyl-1-picrylhydrazyl (DPPH), 2'7'-dichlorodihydrofluorescein diacetate (DCFH-DA), 3-(4,5-dimethylthiazol-2-yl)-2,5-diphenyltetrazolium bromide (MTT), Dimethyl sulfoxide (DMSO), bovine serum albumin (BSA), Folin and Ciocalteu's phenol reagent, ethidium bromide, agarose, 2,2'-azobis(2-amidino-propane) dihydrochloride (AAPH), fluorescein sodium, 6-Hydroxy-2,5,7,8-tetramethylchroman-2-carboxylic acid (Trolox), gallic acid, D-mandelic acid, 2,3,4-trihydroxy benzoic acid, 3,4-dihydroxy benzaldehyde, 4-hydroxy benzoic acid, gentisic acid sodium salt hydrate, catechin hydrate, vanillic acid, 3-hydroxy benzoic acid, chlorogenic acid, syringic acid, p-coumaric acid, 3,4-dimethoxy benzoic acid, sinapic acid, rutin hydrate, trans-cinnamic acid, and quercetin were bought from Sigma-Aldrich (St. Louis, MO, USA). D-glucose was purchased from Junsei Chemical Co., Ltd. (Tokyo, Japan). JC-1 Assay kit was obtained from Thermo Fisher Scientific (Waltham, MA, USA) and Alexa Fluor ${ }^{\circledR} 488$ conjugated Anti-Mouse IgG secondary antibody was purchased from Cell Signaling Technologies (Bedford, MA, USA). Protein assay kit, NE-PER ${ }^{\circledR}$ nuclear and cytoplasmic extraction kit, 1-Step transfer buffer, Pierce ${ }^{\mathrm{TM}}$ RIPA buffer, protein ladder, and SuperSignal ${ }^{\mathrm{TM}}$ West Femto Maximum Sensitivity Substrate were purchased from Thermo Fisher Scientific (Rockford, IL, USA). Antibodies needed for the western blot analysis were purchased from Santa Cruz Biotechnology Inc. (Dallas, TX, USA) and Cell Signaling Technology Inc. (Beverly, MA, USA). Skim milk powder was obtained from BD Difco ${ }^{\mathrm{TM}}$ (Sparks, MD, USA). Normal goat serum, Prolong ${ }^{\circledR}$ Gold antifade reagent with DAPI reagent, and DyLihgtTM 554 Phalloidin were purchased from Cell Signaling Technology (Danvers, MA, USA). The remaining chemicals and reagents used were of analytical grade.

\subsection{Sample Collection and Extraction}

Tender branches and leaves of $M$. oleifera were collected from Suncheon Bay Moringa Cooperative (Suncheon-si, Jeollanam-do, Korea), chopped into about one-centimeter pieces, air-dried under room temperature, and stored in air-tied polythene bags for further uses. A part of the air-dried material was pulverized into powder by using IKA MF10 laboratory pulverizer (Staufen, Germany). Based on the DPPH radical scavenging activity and flavonoid content, one of the previous studies revealed that the $100{ }^{\circ} \mathrm{C}$ water in a pressurized system was the optimum temperature for $M$. oleifera leaf extraction [23]. In this study, boiling water $(900 \mathrm{~mL})$ was used to extract $100 \mathrm{~g}$ of powder at $100{ }^{\circ} \mathrm{C}$ for $4 \mathrm{~h}$. After centrifugation and filtration, the filtrate was frozen at $-80{ }^{\circ} \mathrm{C}$ and freeze-dried to obtain a dry powder of hot water extract. The freeze-dried powder was kept in an air-tight container at $-20^{\circ} \mathrm{C}$. 


\subsection{Compositional Analysis of $\mathrm{MOH}$}

The total polyphenolic content of $\mathrm{MOH}$ was determined using the method outlined by Singleton et al. (1999) [24]. A gradient concentration of gallic acid was used as the reference standard. The Lowry method with BSA as the reference standard was used to determine total protein content in $\mathrm{MOH}$ [25]. Carbohydrate content was measured according to the phenol-sulphuric method using d-glucose as the reference standard [26].

\subsection{High-Performance Liquid Chromatography (HPLC) Analysis of $\mathrm{MOH}$}

HPLC analyses were conducted with the aid of a Shimadzu system equipped with a gradient pump integrated into an SPD-M30A Photodiode Array Detector. The separation was achieved by a Luna PFP (2) 100A $(150 \times 3.0 \mathrm{~mm}, 3 \mathrm{~m})$ column. The system was eluted with the gradient program of a binary solvent system consisting of $0.1 \%$ formic acid in water $(\mathrm{A})$ and $0.1 \%$ formic acid in methanol (B) mixture at a constant flow rate of $0.34 \mathrm{~mL} / \mathrm{min}$. The sample injection volume was $3 \mu \mathrm{L}$. A 5 -min post-run at starting conditions was performed to equilibrate the column. The gradient program was started with $0 \%$ of $\mathrm{B}$ and then changed to obtain $25 \%, 45 \%, 65 \%, 85 \%$, and $100 \%$ of eluent $\mathrm{B}$ at $0,25,50,75,100$, and $125 \mathrm{~min}$, respectively. For each predetermined phenolic compound that was evaluated, the mixed standard solution was prepared by diluting the mixed stock standard solutions in methanol to provide a concentration of $1.176 \mathrm{mg} / \mathrm{mL}$. A solution of $\mathrm{MOH}$ at a concentration of $10 \mathrm{mg} / \mathrm{mL}$ in methanol was prepared, sent through a syringe filter, injected, and phenolic compounds were evaluated using UV absorbance at $270 \mathrm{~nm}$. The phenolic compounds in the $\mathrm{MOH}$ were identified by comparing retention times and absorbance spectrum profiles with the standards of each detected compound. Quantification was carried out by comparing the chromatograms of the standard mixture with that of the sample $(\mathrm{MOH})$. Triplicate independent analyses were conducted, and the results are presented as means \pm standard deviations from three separate studies. All chromatographic processes were carried out at $35^{\circ} \mathrm{C}$, with data acquisition, peak integration, and calculations carried out using LCsolution version 1.24 SP2 software (Shimadzu, Kyoto, Japan).

\subsection{Radical Absorbance Capacity of $\mathrm{MOH}$}

$\mathrm{ABTS}^{+}$and $\mathrm{DPPH}$ radical scavenging activity of $\mathrm{MOH}$ were determined using the methods described in one of the previous studies conducted by Um et al. (2017) [27]. In brief, the stock solution containing ABTS, and potassium persulfate $\left(\mathrm{K}_{2} \mathrm{~S}_{2} \mathrm{O}_{8}\right)$ were mixed with each $50 \mu \mathrm{L}$ of the $\mathrm{MOH}$ hydrolysates $(250 \mu \mathrm{g} / \mathrm{mL})$. Then the mixture was left to react for $10 \mathrm{~min}$ in the dark, and the absorbance was measured at $414 \mathrm{~nm}$ by using a SpectraMax M2 microplate reader (Molecular Devices, Sunnyvale, CA, USA). To analyze the DPPH radical scavenging capacity, $100 \mu \mathrm{L}$ of $\mathrm{MOH}$ hydrolysates $(250 \mu \mathrm{g} / \mathrm{mL})$ was added to $100 \mu \mathrm{L}$ of DPPH solution $(150 \mu \mathrm{M})$. The mixture was kept in dark at room temperature for $30 \mathrm{~min}$, and then absorbance was measured at $517 \mathrm{~nm}$ by using a SpectraMax M2 microplate reader. Ferric chloride (10\% in distilled water) was used to measure the Ferric reducing antioxidant power (FRAP) of MOH. Briefly, 0.1 M phosphate buffer ( $\mathrm{pH}$ 6.6-7.0), $1 \%$ potassium ferricyanide, and sample or distilled water as a control mix in a 3:5:2 ratio, vortexed and incubated for $20 \mathrm{~min}$ at $50{ }^{\circ} \mathrm{C}$. Thereafter, $10 \%$ Trichloroacetic acid was mixed and centrifuged at $3000 \mathrm{rpm}$ for $10 \mathrm{~min}$. The supernatant was taken, mixed with distilled water and $10 \%$ ferric chloride in a 5:5:1 ratio, and the absorbance was measured at $700 \mathrm{~nm}$ by using SpectraMax M2 microplate reader. Oxygen radical absorbance capacity (ORAC) assay was used to examine the antioxidant ability of $\mathrm{MOH}$. In brief, $50 \mu \mathrm{L}$ of $50 \mathrm{~g} / \mathrm{mL}$ $\mathrm{MOH}$ in $75 \mathrm{mM}$ phosphate buffer ( $\mathrm{pH} 7.0$ ) was mixed with $78 \mathrm{nM}$ fluorescein $(440 \mathrm{~g} / \mathrm{mL}$ in $75 \mathrm{mM}$ phosphate buffer) and incubated at $37^{\circ} \mathrm{C}$ for $15 \mathrm{~min}$. Then, $25 \mu \mathrm{L}$ of AAPH was added to each well, and the emission at $538 \mathrm{~nm}$ under $485 \mathrm{~nm}$ excitation was recorded every $5 \mathrm{~min}$ for $2 \mathrm{~h}$ using SpectraMax M2 microplate reader. Trolox $(1,5,10,20$, and $40 \mu \mathrm{M}$ in $75 \mathrm{mM}$ phosphate buffer) was used as the standard. The antioxidant capacity of $\mathrm{MOH}$ was expressed as Trolox equivalents per $\mu \mathrm{g} / \mathrm{mL}$ of $\mathrm{MOH}$. 


\subsection{Cell Culture}

Vero cells (The monkey kidney fibroblasts, KCLB, Seoul, Korea) were cultured and then sub-cultured every 3 days in a humidified atmosphere at $37{ }^{\circ} \mathrm{C}$ with $5 \%$ of $\mathrm{CO}_{2}$ in DMEM supplemented with $1 \% \mathrm{P} / \mathrm{S}$ and $10 \%$ inactivated FBS. Cells were seeded in 24 -well plates or 96-well plates accordingly for subsequent experiments.

\subsection{Cell Viability and ROS Production Analysis}

Vero cells seeded in a 96-well plate were treated with a series of $\mathrm{MOH}$ concentrations and incubated for $1 \mathrm{~h}$. Then, $10 \mu \mathrm{L}$ of $\mathrm{H}_{2} \mathrm{O}_{2}(1 \mathrm{mM})$ was added and incubated at $37^{\circ} \mathrm{C}$ for $24 \mathrm{~h}$. Cells were then subjected to MTT assay. The absorbance of formazan crystals dissolved in DMSO was measured by using SpectraMax M2 microplate reader at $570 \mathrm{~nm}$. Effect of $\mathrm{MOH}$ on intracellular ROS levels in $\mathrm{H}_{2} \mathrm{O}_{2}$-induced Vero cells was measured by $2^{\prime}, 7^{\prime}$-dichlorofluorescein diacetate (DCF-DA) assay. In brief, seeded cells were incubated for $24 \mathrm{~h}$ and then treated with a series of concentrations of $\mathrm{MOH}$ for one hour. Then, $10 \mu \mathrm{L}$ of $\mathrm{H}_{2} \mathrm{O}_{2}(1 \mathrm{mM})$ was added to each well and incubated for another $1 \mathrm{~h}$. Finally, these cells intracellular ROS levels were determined after adding $10 \mu \mathrm{L}$ DCF-DA $(500 \mu \mathrm{g} / \mathrm{mL})$ by using a microplate reader, and images were captured by using Invitrogen ${ }^{\mathrm{TM}}$ EVOS $^{\mathrm{TM}}$ M5000 fluorescence microscope (Thermo Fisher Scientific, Waltham, MA, USA).

\subsection{Evaluation of Apoptotic Body Formation}

The nuclear morphology of the $\mathrm{H}_{2} \mathrm{O}_{2}$-induced Vero cells was observed to identify the apoptotic body formation. For that, seeded cells were treated with a series of $\mathrm{MOH}$ concentrations, incubated for $1 \mathrm{~h}$, and then treated with $1 \mathrm{mM} \mathrm{H}_{2} \mathrm{O}_{2}$. After $24 \mathrm{~h}$, cells were stained with $10 \mu \mathrm{L}$ of Hoechst $33,342(0.5 \mathrm{mg} / \mathrm{mL})$ and propidium iodide $(2.5 \mu \mathrm{M})$. After 10 min of incubation, nuclear morphology was examined by using Invitrogen ${ }^{\mathrm{TM}}$ EVOS $^{\mathrm{TM}}$ M5000 fluorescence microscope.

\subsection{Cell Cycle Analysis}

The cell cycle was investigated according to the procedure described in one of the previous studies [28]. In brief, the cells were rinsed with PBS and permeabilized in 70\% ethanol for $30 \mathrm{~min}$ after harvesting. Then, the cell pellets were centrifuged again after being gently resuspended in PBS containing EDTA. For $30 \mathrm{~min}$, the fresh pellet was gently resuspended in PBS solution containing PI, EDTA, and RNase A. The cells were then examined using a Beckman Colter CytoFLEX system flow cytometer (Brea, CA, USA).

\subsection{Mitochondrial Depolarization Analysis by JC-1 Assay}

Cultured cells were harvested after $4 \mathrm{~h}$ of sample treatment followed by stimulation and the mitochondria membrane potential was measured using MitoProbe JC-1 Assay Kit (Thermo Fisher Scientific, Waltham, MA, USA) according to the manufacturer's instructions followed by flow cytometric analysis.

\subsection{Western Blot Analysis}

Cells were seeded in $10 \mathrm{~cm}$ culture dishes for $24 \mathrm{~h}$ at $2 \times 10^{5}$ cells $/ \mathrm{mL}$ concentration and stimulated with $1 \mathrm{mM} \mathrm{H}_{2} \mathrm{O}_{2}$ after being treated with $15.6,31.3$, and $62.5 \mu \mathrm{g} / \mathrm{mL}$ of $\mathrm{MOH}$ for $2 \mathrm{~h}$. Herein, $50 \mu \mathrm{M}$ vitamin $\mathrm{C}$ was used as a positive control. Then, the cells were harvested for western blot analysis. Insoluble materials were removed from cell lysate by centrifugation followed by lysis. Cells were lysed by a nuclear and cytoplasmic extraction kit, NE-PER ${ }^{\circledR}$ (Thermo Scientific, Rockford, IL, USA). The protein concentrations in cell lysate were estimated using a BCA protein assay kit (Thermo Scientific, Rockford, IL, USA). After estimation was completed, $30 \mu \mathrm{g}$ of protein of each lysate were subjected to electrophoresis on $10 \%$ polyacrylamide gels. Resolved protein bands were transferred onto nitrocellulose membranes (Merck Millipore, Dublin, Ireland), blocked with 5\% skim milk in TBST, and then incubated with primary antibodies and HRP-conjugated secondary antibodies. Then, identified protein bands were visualized by an enhanced chemiluminescence 
(ECL) western blotting detection kit followed by imaging on the Core Bio Davinch-Chemi ${ }^{\mathrm{TM}}$ imaging system (Seoul, Korea).

\subsection{Statistical Analysis}

All the relevant data were presented as the mean \pm standard error of the mean (SEM), while all statistical analyses were performed using the SPSS software (Version 24.0, Chicago, IL, USA). The values were evaluated and significant variations among data sets were obtained by using one-way analysis of variance (ANOVA) followed by Duncan's multiple range tests, and $p<0.05$ was considered as statistically significant.

\section{Results}

\subsection{Extraction Yield and Proximate Composition of $\mathrm{MOH}$}

According to the results indicated in Table 1, the polysaccharide content was relatively higher than the polyphenol composition and protein content of $\mathrm{MOH}$ on a dry basis (\%).

Table 1. Composition of $\mathrm{MOH}$.

\begin{tabular}{cc}
\hline MOH & Composition (\%) \\
\hline Yield & $35.67 \pm 0.44$ \\
Protein & $19.01 \pm 0.27$ \\
Polysaccharide & $44.95 \pm 0.66$ \\
Polyphenol & $5.24 \pm 0.07$ \\
\hline
\end{tabular}

Mean \pm SEM (all experiments were performed in triplicate $(n=3)$ to determine the repeatability).

\subsection{Composition of Antioxidant Phytochemicals in $\mathrm{MOH}$}

HPLC was used to examine phenolic compounds in $\mathrm{MOH}$. The chromatograms obtained by the $\mathrm{MOH}$ were compared to seventeen distinct phenolic standards that had been predetermined (Figure S1). HPLC analysis revealed the presence of fourteen out of seventeen phenolic standards in the $\mathrm{MOH}$. D-mandelic acid, gentisic acid sodium salt hydrate, and syringic acid were not detected in the $\mathrm{MOH}$, but 3-hydroxy benzoic acid was identified in the greatest concentration of $95.64 \pm 0.36 \mu \mathrm{mol} / 100 \mathrm{~g}$, and rutin hydrate was found in the lowest concentration, which was $1.11 \pm 0.43 \mu \mathrm{mol} / 100 \mathrm{~g}$, as shown in Table 2 . Corresponding chromatograms are provided with Supplementary Materials (Figure S1).

Table 2. Availability of the examined phenolic compounds in $\mathrm{MOH}$.

\begin{tabular}{|c|c|}
\hline Phenolic Compound & $\mu \mathrm{mol} / 100 \mathrm{~g}$ \\
\hline Gallic acid & $78.24 \pm 0.18$ \\
\hline D-mandelic acid & Not detected \\
\hline 2,3,4-trihydroxybenzoic acid & $79.00 \pm 0.06$ \\
\hline 3,4-dehydroxybenzaldehyde & $96.87 \pm 0.43$ \\
\hline 4-hydroxybenzoic acid & $97.31 \pm 0.14$ \\
\hline Gentisic acid sodium salt hydrate & Not detected \\
\hline Catechin hydrate & $43.34 \pm 0.26$ \\
\hline Vanillic acid & $79.52 \pm 0.36$ \\
\hline 3-hydroxy benzoic acid & $95.64 \pm 0.36$ \\
\hline Chlorogenic acid & $35.73 \pm 0.03$ \\
\hline Syringic acid & Not detected \\
\hline p-coumaric acid & $81.07 \pm 0.12$ \\
\hline 3,4 dimethoxy benzoic acid & $18.33 \pm 1.26$ \\
\hline Sinapic acid & $60.08 \pm 0.13$ \\
\hline Rutin hydrate & $1.11 \pm 0.43$ \\
\hline Trans-cinnamic acid & $91.66 \pm 0.00$ \\
\hline Quercetin & $45.89 \pm 0.07$ \\
\hline
\end{tabular}

Mean \pm SEM (all experiments were performed in triplicate $(n=3)$ to determine the repeatability). 


\subsection{Antioxidant Activities of $\mathrm{MOH}$}

The decolorization of the $\mathrm{ABTS}^{+}$extent is determined by the percentage inhibition of the $\mathrm{ABTS}^{+}$radical cations $[29,30]$. DPPH absorbs at $515 \mathrm{~nm}$ in the radical form, but this absorption is reduced when it is reduced by an antioxidant or a radical species [29,30]. In the FRAP, the antioxidant activity of an extract is determined based on the ability to reduce ferric (III) iron to ferrous (II) iron. $\mathrm{MOH}$ indicated substantial $\mathrm{ABTS}^{+}$and $\mathrm{DPPH}$ radical scavenging activity with respective $\mathrm{IC}_{50}$ values of 102.52 and $122.55 \mu \mathrm{g} / \mathrm{mL}$ (Figure $1 \mathrm{~A}, \mathrm{C}$ ). Scavenging activity increased with the $\mathrm{MOH}$ concentration, with a maximum scavenging activity of $60.05 \pm 0.24 \%$ and $51.48 \pm 0.41 \%$, respectively, at $125 \mu \mathrm{g} / \mathrm{mL}$. The MOH had a significantly low FRAP value compared to the positive control, vitamin C (Figure 1B). The FRAP of the $\mathrm{MOH}$ indicated a significant and dose-dependent increase with a maximum absorbance of 0.2398 at $125 \mu \mathrm{g} / \mathrm{mL}$ (Figure 1B). The ORAC of the $\mathrm{MOH}$ was $1004.95 \mu \mathrm{mol}$ $\mathrm{TE} / \mathrm{mg}$ of the sample, which is illustrated in Figure 1D.

(A)

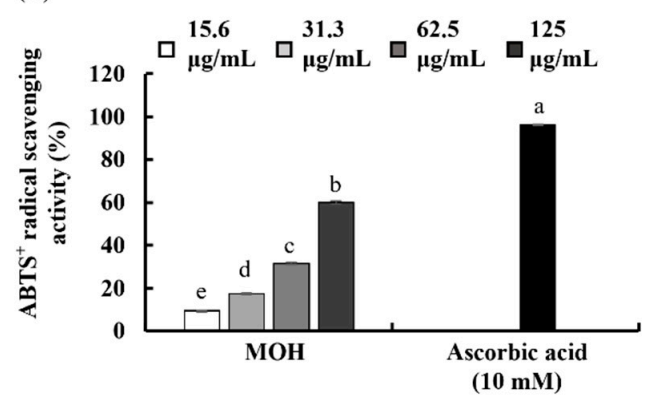

(C)

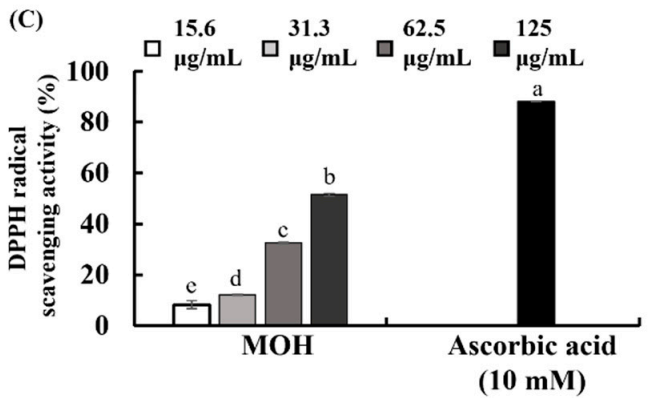

(B)

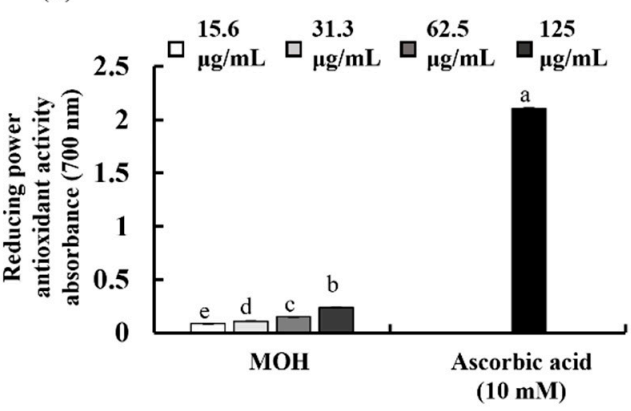

(D)

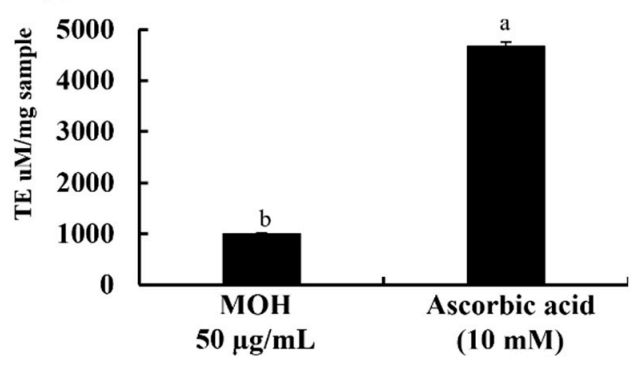

Figure 1. Antioxidant activities of $\mathrm{MOH}$. (A) $\mathrm{ABTS}^{+}$radical scavenging activity, (B) FRAP of MOH, (C) DPPH radical scavenging activity, and (D) ORAC of MOH. Ascorbic acid (Vit C, $10 \mathrm{mM}$ ) was used as the positive control. All experiments were performed in triplicate $(n=3)$ to determine if repeatability and lettered error bars were significantly different $(p<0.05)$.

\subsection{Effects of MOH on Cell Viability and Intracellular ROS Production}

According to measured intracellular ROS inhibition in Vero cells, the $\mathrm{MOH}$ indicated good antioxidant effects. As shown in Figure 2A, the $\mathrm{MOH}$ concentrations used were not cytotoxic towards the Vero cells up to $125 \mu \mathrm{g} / \mathrm{mL}$. Therefore, the concentrations of $15.6 \mu \mathrm{g} / \mathrm{mL}, 31.3 \mu \mathrm{g} / \mathrm{mL}$, and $62.5 \mu \mathrm{g} / \mathrm{mL}$ were used throughout the study. Contrary to this, the cell viability of $\mathrm{H}_{2} \mathrm{O}_{2}$-induced Vero cells was decreased compared to control cells, while $\mathrm{MOH}$-treated cells showed an increase in dose-dependent cell viability $(31.3-125 \mu \mathrm{g} / \mathrm{mL})$ (Figure 2C). Vitamin $\mathrm{C}$ was used as a positive control. $\mathrm{H}_{2} \mathrm{O}_{2}$ boosted the intracellular ROS production in Vero cells and showed a reduction in ROS production in a dose-dependent manner by $\mathrm{MOH}$-pretreated cells (Figure 2B). Figure 2D indicates the fluorescence microscopy analysis of the inhibitory effects of the $\mathrm{MOH}$ against $\mathrm{H}_{2} \mathrm{O}_{2}$-induced oxidative stress in Vero cells. According to the results, $\mathrm{H}_{2} \mathrm{O}_{2}$-stimulated cells unveiled higher green fluorescence for DCFH-DA compared to the control group. MOH-pretreated Vero cells indicated a dose-dependent reduction in the green fluorescence supporting the poten- 
tial antioxidant activities of $\mathrm{MOH}$ against $\mathrm{H}_{2} \mathrm{O}_{2}$-induced intracellular ROS generation in Vero cells.

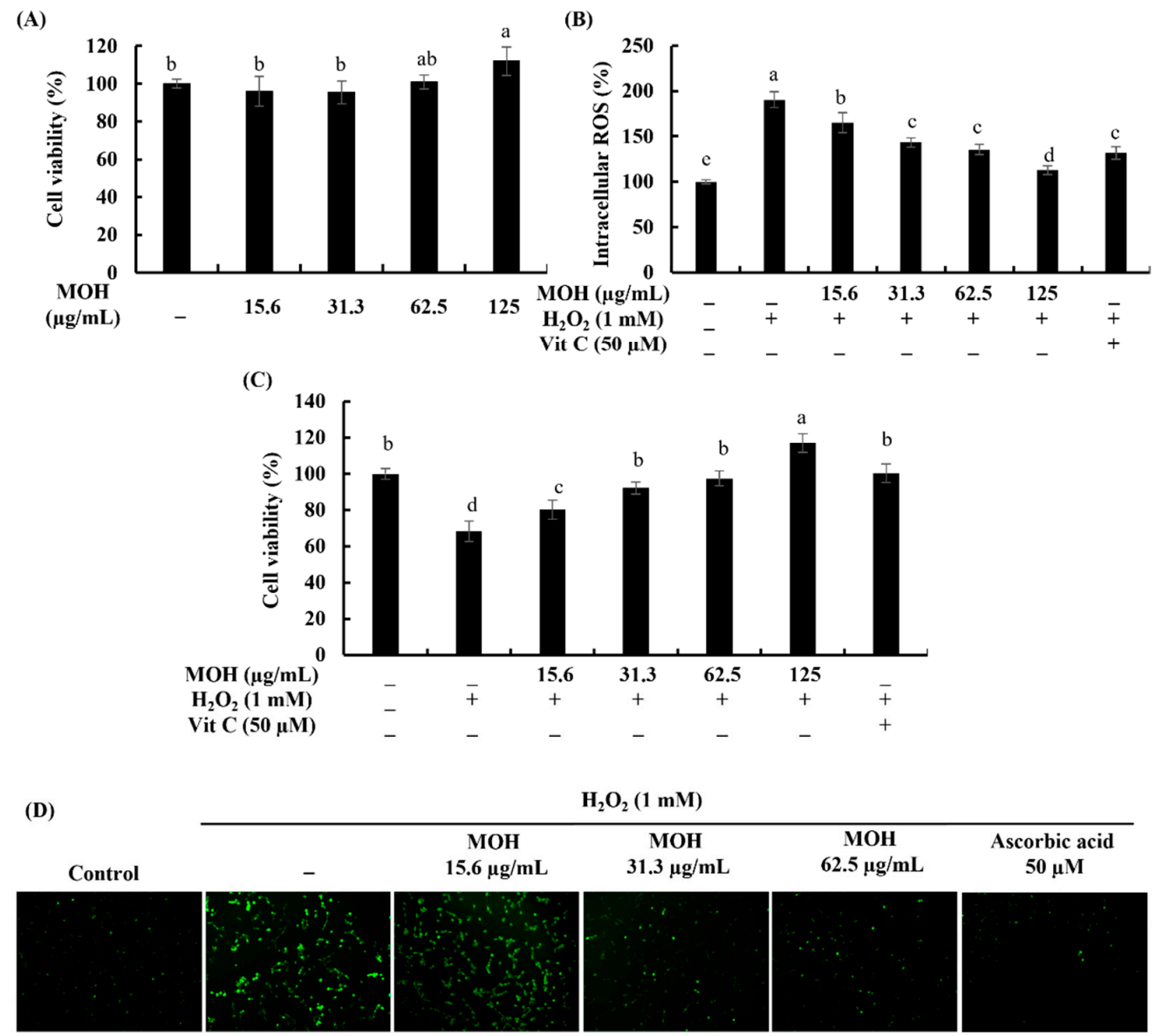

Figure 2. Cytoprotective effects of $\mathrm{MOH}$ against $\mathrm{H}_{2} \mathrm{O}_{2}$-induced Vero cells. (A) Cytotoxicity, (B) intracellular ROS generation, $(\mathbf{C})$ cell viability, and analysis of ROS generation through (D) fluorescence microscopy with $2^{\prime}, 7^{\prime}$-dichlorofluorescein diacetate (DCFH-DA) staining of $\mathrm{MOH}$-pretreated $\mathrm{H}_{2} \mathrm{O}_{2}$ induced Vero cells. Ascorbic acid (Vit C, $50 \mu \mathrm{M})$ was used as the positive control. All experiments were performed in triplicate $(n=3)$ to determine if repeatability and lettered error bars were significantly different $(p<0.05)$.

\subsection{Effect of $\mathrm{MOH}$ on $\mathrm{H}_{2} \mathrm{O}_{2}$-Induced Apoptosis}

In the Hoechst (33342) and PI nuclear double staining, cells with equally stained nuclei are considered viable cells, where chromatin condensation and fragmentation indicate apoptosis, and red to orange nuclei indicate necrotic death of cells [31]. As Figure 3A indicates, $\mathrm{H}_{2} \mathrm{O}_{2}$-induced Vero cells indicated nuclear condensation and fragmentation. Dose-dependent treatment of the $\mathrm{MOH}$ reduced the formation of the apoptotic bodies by reducing the condensation of chromatin and nuclear fragmentation. $\mathrm{H}_{2} \mathrm{O}_{2}$-induced Vero cells without pretreatment of the $\mathrm{MOH}$ showed necrotic cells. These results were compatible with the results of the cell cycle analysis conducted with flow cytometry. Cell cycle analysis was performed after PI staining to test if the cells were undergoing apoptosis. The hypodiploid cell population in the Sub- $\mathrm{G}_{1}$ phase was analyzed by flow cytometry. According to the findings (Figure 3B), an increase in the Sub- $\mathrm{G}_{1}$ apoptotic cell population (32.72\%) further indicates $\mathrm{H}_{2} \mathrm{O}_{2}$-induced apoptosis compared to the nonstimulated control $(1.78 \%)$. The $\mathrm{MOH}$ treatment dose-dependently reduced the Sub- $\mathrm{G}_{1}$ apoptotic cell population. 
(A)

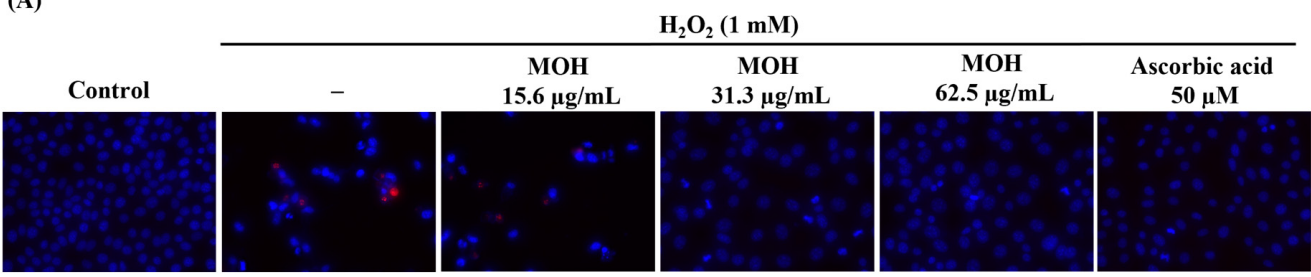

(B)

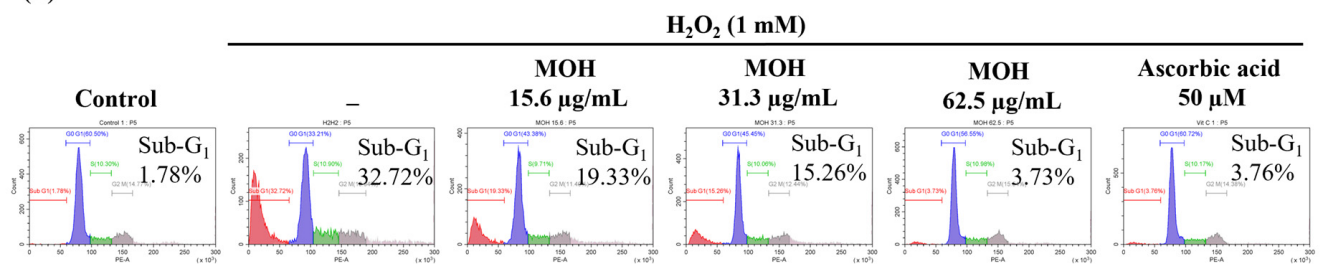

Figure 3. Effect of $\mathrm{MOH}$ on $\mathrm{H}_{2} \mathrm{O}_{2}$-induced apoptosis in Vero cell. (A) Evaluation of apoptotic body formation and necrosis by Hoechst 33342 and PI Nuclear double staining. (B) Analysis of Sub-G apoptotic populations by flow cytometry using PI. All experiments were performed in triplicate $(n=3)$ to determine repeatability.

3.6. Effect of $\mathrm{MOH}$ on Mitochondrial Depolarization and Expression Levels of the Proteins Related to Mitochondrial Apoptosis Pathway

The JC-1 (5,5',6,6'-tetrachloro-1,1',3,3'-tetraethylbenzimidazolyl carbocyanine iodide) has been used for many years as a specific membrane-permeable dye for measuring mitochondrial membrane potential. Emission of the red color indicates healthy mitochondria. The decreased potential of the mitochondrial membrane causes a significant shift in the blue laser excitation from orange to green fluorescence emissions at $488 \mathrm{~nm}$. Based on the data shown in Figure 4A, a comparatively large number of cells (93.07\%) indicated red fluorescence in the control. Stimulated cells denoting the lowest number of cells with red fluorescence represent that $\mathrm{H}_{2} \mathrm{O}_{2}$ increases the population of hyperpolarized mitochondria in $\mathrm{H}_{2} \mathrm{O}_{2}$-induced Vero cells. Moreover, Figure 4A exhibits fluorescence microscopic images that indicate the visual condition of the cells used in flow cytometry. $\mathrm{MOH}$ treatment dosedependently decreased the population of hyperpolarized mitochondria in $\mathrm{H}_{2} \mathrm{O}_{2}$-induced Vero cells, whereas $62.5 \mu \mathrm{g} / \mathrm{mL}$ of $\mathrm{MOH}$ showed the best protective effect against $\mathrm{H}_{2} \mathrm{O}_{2}$. The positive control, vitamin $\mathrm{C}$ indicated the highest protective effect against $\mathrm{H}_{2} \mathrm{O}_{2}$ in Vero cells at $50 \mu \mathrm{M}$.

Results from nuclear double staining with Hoechst and PI and JC-1 assay, predicted that apoptosis in $\mathrm{H}_{2} \mathrm{O}_{2}$-induced Vero cells happened through a mitochondria-mediated apoptotic pathway. To examine the mitochondria-mediated apoptosis, levels of Bcl-xL, Bcl-2, Bax, caspase 3, p53, cleaved PARP, cleaved caspase 9, and cytochrome c were investigated by using western blotting. Figure $4 \mathrm{~B}$ shows that $\mathrm{Bcl}-\mathrm{xL}$ and $\mathrm{Bcl}-2$ were suppressed and Bax, caspase 3, p53, cleaved PARP, cleaved caspase 9, and cytochrome c were increased by $\mathrm{H}_{2} \mathrm{O}_{2}$ in Vero cells. Hence, $\mathrm{MOH}$ controls the mitochondria-mediated apoptosis by increasing the levels of Bcl-xL and Bcl-2 and decreasing the levels of BAX, Caspase 3, p53, cleaved PARP, cleaved caspase 9, and cytochrome c (Figure 4B). The suppression of apoptosis was mediated via the mitochondrial apoptosis pathway.

\subsection{Effect of $\mathrm{MOH}$ on Activation of Nrf2/HO-1/NQO1 Signaling Pathway}

Activation of the nuclear factor erythroid 2-related factor 2 (Nrf2)/heme oxygenase 1 (HO-1) signaling pathway has been shown to reduce ROS generation in cells in previous research [32]. The presence of green fluorescence in the nucleus can be used to identify Nrf2 nuclear translocation in an immunostaining experiment. The strong green fluorescent signal implies that Nrf2 nuclear translocation is increasing. Figure 5A shows that pretreatment with the $\mathrm{MOH}$ enhanced $\mathrm{Nrf} 2$ signaling in $\mathrm{H}_{2} \mathrm{O}_{2}$-stimulated Vero cells by boosting $\mathrm{Nrf} 2$ nuclear translocation in a dose-dependent manner. According to the results of western blot 
analysis, $\mathrm{H}_{2} \mathrm{O}_{2}$-stimulation raised the levels of nuclear $\mathrm{Nrf2}$ as well as cytosolic $\mathrm{HO}-1$ and NQO1 in Vero cells, followed by a substantial and dose-dependent increase in the levels of nuclear Nrf2 (Figure 5B).

(A)
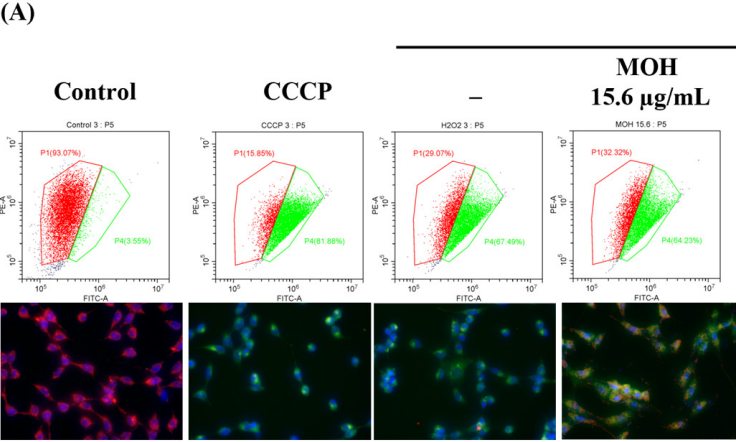

$\mathrm{H}_{2} \mathrm{O}_{2}(\mathbf{1} \mathrm{mM})$
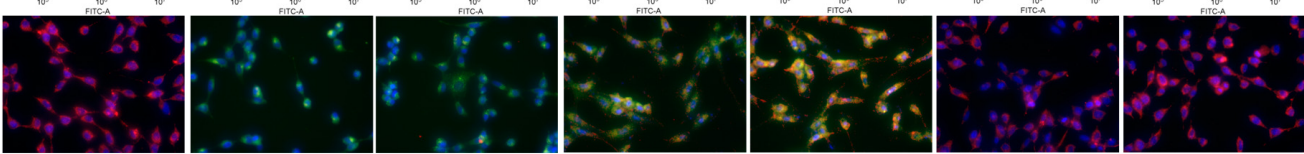

(B)

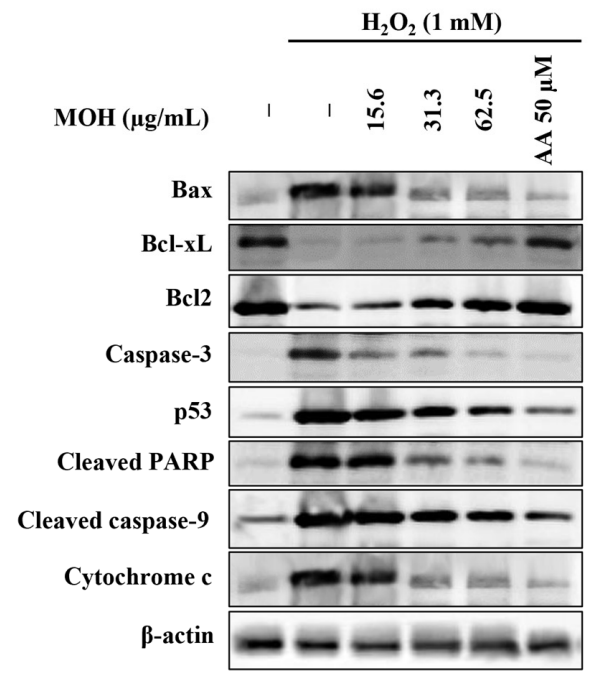

Figure 4. Effect of $\mathrm{MOH}$ on (A) mitochondrial depolarization and (B) variation in mitochondriamediated apoptotic pathway proteins expression levels against $\mathrm{H}_{2} \mathrm{O}_{2}$-induced apoptosis in Vero cell. All experiments were performed in triplicate $(n=3)$ to determine repeatability.

(A)
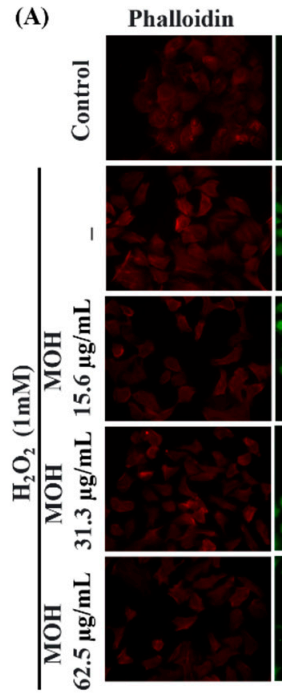
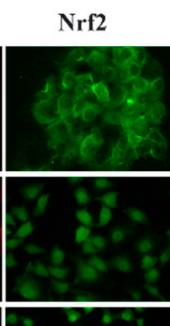
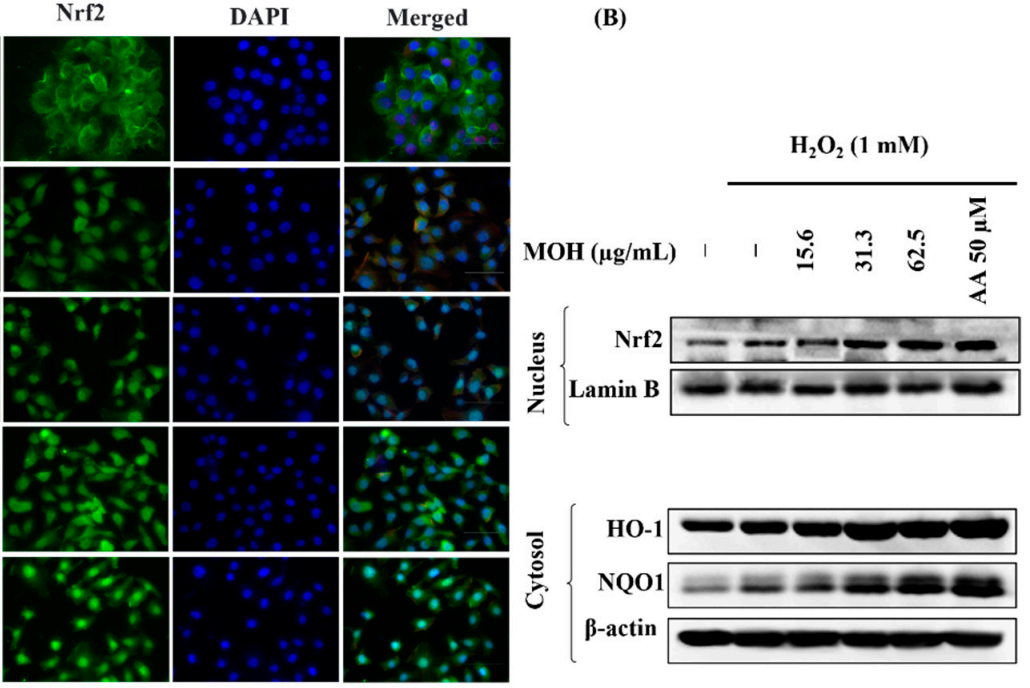

Figure 5. (A) Immunofluorescence analysis of Nrf2 nuclear translocation and (B) dose-dependent variation of the effects of $\mathrm{MOH}$ on Nrf2-mediated activation of $\mathrm{HO}-1$ and $\mathrm{NQO} 1$ in $\mathrm{H}_{2} \mathrm{O}_{2}$-induced Vero cells. 


\section{Discussion}

The existence of selected phenolic components in Moringa oleifera hot water extract $(\mathrm{MOH})$ and its antioxidant activity against $\mathrm{H}_{2} \mathrm{O}_{2}$-induced oxidative stress in Vero cells were investigated in this study. The hot water extraction method was selected to extract $M$. oleifera because of its efficiency with a reduced cost. In addition, the hot water extraction method is useful in industry and can be used to extract ingredients for food and cosmetics [33]. Based on the outcomes of the study, the extraction yield of $\mathrm{MOH}$ was $35.67 \pm 0.44 \%$, while the previous study reported a yield of $28.26 \%$ per 90 min soaking at $121 \pm 0.5{ }^{\circ} \mathrm{C}$ water [33]. According to the current observations, $\mathrm{MOH}$ had a relatively high polysaccharide content compared with protein while having a comparatively low polyphenol content. The present study reports polyphenol content of $5.24 \pm 0.07 \%(w / w)$ in $\mathrm{MOH}$, while Sreelatha, S. and Padma, P.R. (2009) reported 4.58\% in Soxhlet extraction for 18-20 h of M. oleifera leaves [34]. Polyphenols are recognized as antioxidants due to their hydroxyl groups' capacity to scavenge free radicals, which have a significant in vitro effect [34,35]. Glucosinolates, and potentially alkaloids, in addition to polyphenols, are thought to be responsible for the bioactive effects of $M$. oleifera as reported before [36]. Pawlowska, E. et al. particularly mentioned the presence of two hydroxyl groups in their B ring structure in some dietary polyphenols, such as quercetin and cyanidin-3-glucoside affect directly to scavenge ROS in cells [37]. Young Chool Boo reported that the phenolic compounds derived from a variety of plants can lower the levels of ROS in cells and/or enhance cellular antioxidant capacity and anti-inflammatory effects [38]. Aside from direct ROS scavenging, dietary phenols can reduce oxidative stress through a variety of mechanisms such as inducing Nrf2 activation [37]. Kanner J.'s review contains evidence that polyphenols can inhibit cellular protein tyrosine phosphatases and activate cell signaling through transcription of the Nrf2 axis to adapt and protect cells against oxidative stress by producing $\mathrm{H}_{2} \mathrm{O}_{2}$ at low levels $(1-10 \mu \mathrm{M})$ [39]. In this study, the presence of gallic acid, 2,3,4-trihydroxy benzoic acid, 3,4-dehydroxy benzaldehyde, 4-hydroxy benzoic acid, catechin hydrate, vanillic acid, 3-hydroxy benzoic acid, chlorogenic acid, p-coumaric acid, 3,4 dimethoxy benzoic acid, sinapic acid, rutin hydrate, trans-cinnamic acid, and quercetin in the $\mathrm{MOH}$ were confirmed based on the results obtained from HPLC analysis (Supplementary Material Figure S1). According to the results, the total polyphenolic content on a weight basis was found to be $136.28 \mathrm{mg} / 100 \mathrm{~g}$. Quercetin-like phenolics were present in the $\mathrm{MOH}$, which can be implicated to have positive benefits on human health and to alleviate oxidative stress [40]. Based on the findings, a quantitative difference was observed between total polyphenolic content as determined by proximate composition analysis and HPLC analysis. This suggests that $\mathrm{MOH}$ may contain a range of additional polyphenolic compounds, which was not revealed by HPLC analysis in this study. Due to the presence of phenolic compounds in $\mathrm{MOH}, \mathrm{H}_{2} \mathrm{O}_{2}$ production in Vero cell-cultured media after treatment of $\mathrm{MOH}$ for $1 \mathrm{~h}$ was analyzed. According to the results obtained from the analysis, it revealed that $\mathrm{MOH}$ produces a maximum quantity of $0.235 \pm 0.033 \mu \mathrm{M}$ of $\mathrm{H}_{2} \mathrm{O}_{2}$ in cell culture media at $62.5 \mu \mathrm{g} / \mathrm{mL}$ of $\mathrm{MOH}$ concentration (Supplementary Material Figure S3). In this study, TLC analysis (Supplementary Material Figure S2) verified the existence of antioxidative chemicals in $\mathrm{MOH}$ seen from the change of color in $\mathrm{KMnO}_{4}$-stained TLC. The discoloration of $\mathrm{KMnO}_{4}$ is caused by a reduction in the oxidative state of $\mathrm{Mn}$ from +7 to +2 [41]. Furthermore, the occurrence of nucleophiles, aldehydes, and ketones was confirmed by $p$-anisaldehyde and Vanillin stains, which commonly undergo Aldol condensation and acetalization [42]. UV light with a short wavelength and long wavelength (254 $\mathrm{nm}$ and $365 \mathrm{~nm}$, respectively) to enable visualization of TLCs, can be used to identify extended conjugated (aromatic) systems [42]. Bright purple or blue fluorescent represents highlyconjugated compounds, which may be comprised of a single or multiple aromatic rings. Accordingly, the presence of single or multiple aromatic rings in the $\mathrm{MOH}$ was confirmed by UV-enabled visualization of TLCs. Unsaturated and aromatic compounds were visualized in a brown color by iodine stains. Saponins and phenols were visualized by the $10 \%$ sulphuric acid in ethanol and the ferric chloride stains, respectively [42]. 
The $\mathrm{ABTS}^{+}$diammonium salt radical cation decolorization test is one of the commonly used spectrophotometric methods to evaluate the antioxidant activity of numerous substances, including plant extracts [43]. $2^{\prime}, 7^{\prime}$-dichlorodihydrofluorescein (DCFH) is highly sensitive to ROS and can be oxidized to a highly fluorescent $2^{\prime}, 7^{\prime}$-dichlorofluorescein (DCF) by ROS [44]. DCF can be seen with green fluorescence in fluorescence microscopic observations. During reactions between DPPH radicals and antioxidative extracts or antioxidative compounds, the absorption reduction with a characteristic wavelength is widely used to evaluate antioxidative activity that can give hydrogen [45]. The ABTS assay revealed that ABTS+ radical scavenging activity increases dose-dependently with the MOH. Antioxidant capabilities in fruit, vegetables, and other plant materials as well as their products, have been determined using the DPPH and ORAC assays. Because it uses a biologically relevant radical source, the ORAC assay is believed to be more relevant [46]. The finding of the ABTS assay was strengthened by DPPH scavenging activity and an ORAC value of the MOH. Further analyses were conducted to evaluate the protective effect of the $\mathrm{MOH}$ against $\mathrm{H}_{2} \mathrm{O}_{2}$-induced oxidative stress in Vero cells based on the promising radical scavenging capacity exhibited by the $\mathrm{MOH}$.

$\mathrm{H}_{2} \mathrm{O}_{2}$ treatment raised intracellular ROS levels in cells, resulting in enhanced oxidative stress in Vero cells. The results of the present MTT and DCF-DA analysis indicate that MOH has promising antioxidant and protective effects in Vero cells against the $\mathrm{H}_{2} \mathrm{O}_{2}$-induced oxidative stress. The outcomes of the investigation of DCF-DA-stained cells by fluorescence microscopy indicated parallel results to the fluorometric analysis of Sub-G $\mathrm{G}_{1}$ apoptotic populations, revealing the effects of the $\mathrm{MOH}$ against $\mathrm{H}_{2} \mathrm{O}_{2}$-induced oxidative stress. Based on simultaneous DCF fluorescence changes, one of the previous studies confirmed flavonoids cell membrane permeability and disclosed that polyphenolic compounds (particularly myricetin in the relevant study) can diffuse through the cell membrane into the cells, where they prevent the production of different ROS compounds in the polar intracellular environment [47]. In that sense, the antioxidant effect of the $\mathrm{MOH}$ on cells can be justified since it contains numerous phenolic compounds.

Chromatin condensation, membrane surface hemorrhage, phosphatidylserine excretion, DNA fragmentation, and eventual apoptotic body formation are specific morphological and biochemical features associated with apoptosis [48]. Results obtained from the nuclear double staining analysis with Hoechst and PI in this study indicated the effects of $\mathrm{MOH}$ on the reduction of the events of apoptosis, including the formation of the apoptotic bodies and DNA damage. The above observations can be presented as evidence of the protective potential of $\mathrm{MOH}$ on Vero cells against oxidative stress induced by $\mathrm{H}_{2} \mathrm{O}_{2}$. Moreover, the above finding was confirmed by the reduction in Sub- $\mathrm{G}_{1}$ apoptotic cells accumulation along with the results of the JC- 1 assay. Collectively, the above evidence suggested the effectiveness of $\mathrm{MOH}$ in ameliorating apoptosis in $\mathrm{H}_{2} \mathrm{O}_{2}$-induced Vero cells and the connection between the inhibition of mitochondrial dysfunction and $\mathrm{H}_{2} \mathrm{O}_{2}$-induced apoptosis progression. Based on the above outcomes, further experiments were designed to obtain a better understanding of the role of $\mathrm{MOH}$ in apoptosis pathway regulation.

The mitochondria-mediated caspase activation apoptosis pathway is one of the major signaling pathways that mediate apoptosis in the mammalian cells, with the characteristic permeabilization of the mitochondrial external membrane and consequent release of cytochrome $\mathrm{c}$ to the cytoplasm [49]. Many studies have reported that the regulation of this pathway depends on various factors including the type of apoptotic stimulant as well as the type of cell undergoing apoptosis [50]. Suppression of the above pathway reduces apoptosis, thereby minimizing the relevant responses such as limiting non-communicable illnesses. $\mathrm{Bcl}-2$ family proteins including antiapoptotic Bcl-2 and $\mathrm{Bcl}-\mathrm{xL}$, and pro-apoptotic proteins including Bax, Bak, Bok, Bad, Bid, Bik, Bim, Bmf, Puma, and Noxa are identified as major responsible proteins that control mitochondrial outer membrane permeabilization [50]. The activation of caspase 9 causes the progression of apoptosis. Caspase 9 becomes cleaved caspase 9 when it meets cytochrome c. Mitochondrial pathway-mediated apoptosis is further aggravated by pro-apoptotic stimuli inducing p53, activated caspase- 9 and, consequently, 
activating downstream effector caspases such as caspase $-3,-6$, and -7 . The catalytic activity of PARP is inhibited by effector caspases by cleaving PARP. The present study clarified the effect of $\mathrm{H}_{2} \mathrm{O}_{2}$ on the initiation of mitochondria-mediated apoptosis proteins and the dose-dependent attenuation effects of $\mathrm{MOH}$.

The Nrf2-Keap1 system is a physiological thiol-based sensor-effect system in eukaryotes that responds to oxidative stress by maintaining redox homeostasis [5]. Nrf2 has been identified as the primary regulator of the transcription of several antioxidant and cytoprotective genes, whereas regulating oxidative stress and securing physiological homeostasis requires the regulation of antioxidant gene expression. Nrf2 is typically found in the cytosol due to its interaction with a cytosolic actin-binding protein called Keap1 (Kelch-like ECH-associated protein 1), also known as INrf2 (inhibitor of Nrf2) [51]. When cells encounter stress, such as exposure to mild oxidants, Nrf2 dissociates from Keap1, becomes stabilized, and translocases into the nuclei, and promotes the antioxidant response element-driven antioxidant gene transcription of numerous antioxidant genes, including NQO1, HO-1, glutathione S-transferase A2, and glutamate-cysteine ligase [52]. The results of the immunofluorescence analysis of $\mathrm{Nrf} 2$ nuclear translocation in $\mathrm{H}_{2} \mathrm{O}_{2}$-induced Vero cells reveal that $\mathrm{Nrf} 2$ activation and nuclear translocation were increased by $\mathrm{H}_{2} \mathrm{O}_{2}$ stimulation and dose-dependently upregulated by the $\mathrm{MOH}$ in Vero cells. Apart from the scavenging of ROS in the cytosol by phenolic compounds, several studies have revealed that the nanomolar range of $\mathrm{H}_{2} \mathrm{O}_{2}$ generated in the cell growth media could be penetrating cells, activating Nrf2 signaling, and supporting to adapt to changes in the environment and oxidative stress [39,53]. Moreover, $\mathrm{H}_{2} \mathrm{O}_{2}$ is acknowledged as the most important $\mathrm{ROS}$ in the redox regulation of biological processes [5]. The activation of Nrf2 signaling in Vero cells can be explained by the fact that $\mathrm{MOH}$ generated low levels of $\mathrm{H}_{2} \mathrm{O}_{2}$ in the cell growth medium after $\mathrm{MOH}$ incubation. Furthermore, western blot analysis, which was conducted to investigate the effect of $\mathrm{MOH}$ on $\mathrm{H}_{2} \mathrm{O}_{2}$-induced Vero cells, shows a significant increment of expression levels of nuclear Nrf2, cytosolic $\mathrm{HO}-1$, and NQO1 with the $\mathrm{MOH}$ strengthened the antioxidant activity of the $\mathrm{MOH}$ on $\mathrm{H}_{2} \mathrm{O}_{2}$-induced Vero cells.

\section{Conclusions}

Based on the present study, hot water extract of $M$. oleifera $(\mathrm{MOH})$ has various phenolic compounds that possess potent antioxidant activity and have an ability to generate a low level of $\mathrm{H}_{2} \mathrm{O}_{2}$ in Vero cell-cultured media, which collectively ameliorate $\mathrm{H}_{2} \mathrm{O}_{2}$-induced oxidative stress and apoptosis in Vero cells by suppressing the mitochondria-mediated apoptosis pathway and regulating the Nrf2/HO-1 signaling pathway. Further analysis of $\mathrm{MOH}$ bioactivity and safety would potentiate its applications in the manufacturing of functional foods with beneficial bioactivities centered on their antioxidant activity.

Supplementary Materials: The following supporting information can be downloaded at: https: / www. mdpi.com/article/10.3390/foods11030420/s1, Figure S1: HPLC chromatography of MOH, Figure S2: Thin-layer chromatography (TLC) analysis of $\mathrm{MOH}$, Figure S3: $\mathrm{H}_{2} \mathrm{O}_{2}$ production levels in Vero cellcultured media after treatment of $\mathrm{MOH}$ for one hour.

Author Contributions: Conceptualization, K.G.I.S.K., I.P.S.F. and G.A.; methodology, K.G.I.S.K., T.-S.S. and M.K.H.M.D.; validation, I.P.S.F. and E.-J.H.; formal analysis, K.G.I.S.K., A.M., T.-S.S. and M.K.H.M.D.; investigation, K.G.I.S.K., A.M.K.J., A.M. and E.-J.H.; resources, G.A., I.P.S.F., K.-P.K. and S.-I.M.; data curation, K.G.I.S.K. and A.M.K.J.; writing-original draft preparation, K.G.I.S.K.; writing-review and editing, I.P.S.F.; visualization, I.P.S.F., A.M.K.J. and M.K.H.M.D.; supervision, I.P.S.F. and G.A.; project administration, G.A.; funding acquisition, I.P.S.F., K.-P.K. and S.-I.M. All authors have read and agreed to the published version of the manuscript.

Funding: Research funded by Small and Medium Business Administration (S2838176).

Institutional Review Board Statement: Not applicable.

Informed Consent Statement: Not applicable. 
Data Availability Statement: The data presented in this study are available on request from the corresponding author.

Conflicts of Interest: The authors declare no conflict of interest.

\section{References}

1. Zuo, L.; Prather, E.R.; Stetskiv, M.; Garrison, D.E.; Meade, J.R.; Peace, T.I.; Zhou, T. Inflammaging and oxidative stress in human diseases: From molecular mechanisms to novel treatments. Int. J. Mol. Sci. 2019, 20, 4472. [CrossRef] [PubMed]

2. Seyedsadjadi, N.; Grant, R. The Potential Benefit of Monitoring Oxidative Stress and Inflammation in the Prevention of NonCommunicable Diseases (NCDs). Antioxidants 2021, 10, 15. [CrossRef] [PubMed]

3. Tabriziani, H.; Lipkowitz, M.S.; Vuong, N. Chronic kidney disease, kidney transplantation and oxidative stress: A new look to successful kidney transplantation. Clin. Kidney J. 2018, 11, 130-135. [CrossRef] [PubMed]

4. Suraweera, T.L.; Rupasinghe, H.; Dellaire, G.; Xu, Z. Regulation of Nrf2/ARE pathway by dietary flavonoids: A friend or foe for cancer management? Antioxidants 2020, 9, 973. [CrossRef] [PubMed]

5. Sies, H.; Jones, D.P. Reactive oxygen species (ROS) as pleiotropic physiological signalling agents. Nat. Rev. Mol. Cell Biol. 2020, 21, 363-383. [CrossRef] [PubMed]

6. Wang, L.; Oh, J.Y.; Kim, H.S.; Lee, W.; Cui, Y.; Lee, H.G.; Kim, Y.-T.; Ko, J.Y.; Jeon, Y.-J. Protective effect of polysaccharides from Celluclast-assisted extract of Hizikia fusiforme against hydrogen peroxide-induced oxidative stress in vitro in Vero cells and in vivo in zebrafish. Int. J. Biol. Macromol. 2018, 112, 483-489. [CrossRef]

7. Ozbek, E. Induction of oxidative stress in kidney. Int. J. Nephrol. 2012, 2012, 465897. [CrossRef]

8. Honda, T.; Hirakawa, Y.; Nangaku, M. The role of oxidative stress and hypoxia in renal disease. Kidney Res. Clin. Pract. 2019, 38, 414. [CrossRef]

9. $\quad$ Cheng, S.-B.; Liu, H.-T.; Chen, S.-Y.; Lin, P.-T.; Lai, C.-Y.; Huang, Y.-C. Changes of oxidative stress, glutathione, and its dependent antioxidant enzyme activities in patients with hepatocellular carcinoma before and after tumor resection. PLoS ONE 2017, 12, e0170016. [CrossRef]

10. Basile, D.P.; Bonventre, J.V.; Mehta, R.; Nangaku, M.; Unwin, R.; Rosner, M.H.; Kellum, J.A.; Ronco, C. Progression after AKI: Understanding maladaptive repair processes to predict and identify therapeutic treatments. J. Am. Soc. Nephrol. 2016, 27, 687-697. [CrossRef]

11. Nangaku, M.; Hirakawa, Y.; Mimura, I.; Inagi, R.; Tanaka, T. Epigenetic changes in the acute kidney injury-to-chronic kidney disease transition. Nephron 2017, 137, 256-259. [CrossRef] [PubMed]

12. Tucker, P.S.; Scanlan, A.T.; Dalbo, V.J. Chronic kidney disease influences multiple systems: Describing the relationship between oxidative stress, inflammation, kidney damage, and concomitant disease. Oxid. Med. Cell. Longev. 2015, 2015, 806358. [CrossRef] [PubMed]

13. Engwa, G.A. Free radicals and the role of plant phytochemicals as antioxidants against oxidative stress-related diseases. In Phytochemicals: Source of Antioxidants and Role in Disease Prevention; Asaduzzaman, M., Asao, T., Eds.; IntechOpen: London, UK, 2018; Volume 7, pp. 49-74.

14. Ribeiro, J.S.; Santos, M.J.M.C.; Silva, L.K.R.; Pereira, L.C.L.; Santos, I.A.; da Silva Lannes, S.C.; da Silva, M.V. Natural antioxidants used in meat products: A brief review. Meat Sci. 2019, 148, 181-188. [CrossRef] [PubMed]

15. Xu, D.-P.; Li, Y.; Meng, X.; Zhou, T.; Zhou, Y.; Zheng, J.; Zhang, J.-J.; Li, H.-B. Natural antioxidants in foods and medicinal plants: Extraction, assessment and resources. Int. J. Mol. Sci. 2017, 18, 96. [CrossRef] [PubMed]

16. Lin, M.; Zhang, J.; Chen, X. Bioactive flavonoids in Moringa oleifera and their health-promoting properties. J. Funct. Foods 2018, 47, 469-479. [CrossRef]

17. Chumark, P.; Khunawat, P.; Sanvarinda, Y.; Phornchirasilp, S.; Morales, N.P.; Phivthong-Ngam, L.; Ratanachamnong, P.; Srisawat, S.; Klai-upsorn, S.P. The in vitro and ex vivo antioxidant properties, hypolipidaemic and antiatherosclerotic activities of water extract of Moringa oleifera Lam. leaves. J. Ethnopharmacol. 2008, 116, 439-446. [CrossRef] [PubMed]

18. Vongsak, B.; Gritsanapan, W.; Wongkrajang, Y.; Jantan, I. In vitro inhibitory effects of Moringa oleifera leaf extract and its major components on chemiluminescence and chemotactic activity of phagocytes. Nat. Prod. Commun. 2013, 8, 1934578X1300801115. [CrossRef]

19. Nouman, W.; Anwar, F.; Gull, T.; Newton, A.; Rosa, E.; Domínguez-Perles, R. Profiling of polyphenolics, nutrients and antioxidant potential of germplasm's leaves from seven cultivars of Moringa oleifera Lam. Ind. Crops Prod. 2016, 83, 166-176. [CrossRef]

20. Vergara-Jimenez, M.; Almatrafi, M.M.; Fernandez, M.L. Bioactive components in Moringa oleifera leaves protect against chronic disease. Antioxidants 2017, 6, 91. [CrossRef]

21. Sarkar, M.; Bhowmick, S.; Hussain, J.; Hasan, M.; Hossain, S. Hot Water Extract of Moringa oleifera Leaves Protects Erythrocytes from Hemolysis and Major Organs from Oxidative Stress in vitro. J. Basic Appl. Res. Biomed. 2017, 3, $120-126$.

22. Fernando, I.P.S.; Sanjeewa, K.K.A.; Samarakoon, K.W.; Lee, W.W.; Kim, H.S.; Jeon, Y.J. Squalene isolated from marine macroalgae Caulerpa racemosa and its potent antioxidant and anti-inflammatory activities. J. Food Biochem. 2018, 42, e12628. [CrossRef]

23. Matshediso, P.G.; Cukrowska, E.; Chimuka, L. Development of pressurised hot water extraction (PHWE) for essential compounds from Moringa oleifera leaf extracts. Food Chem. 2015, 172, 423-427. [CrossRef] 
24. Singleton, V.L.; Orthofer, R.; Lamuela-Raventós, R.M. [14] Analysis of total phenols and other oxidation substrates and antioxidants by means of folin-ciocalteu reagent. In Methods in Enzymology; Packer, L., Ed.; Elsevier: Amsterdam, The Netherlands, 1999; Volume 299, pp. 152-178.

25. Mæhre, H.K.; Dalheim, L.; Edvinsen, G.K.; Elvevoll, E.O.; Jensen, I.-J. Protein determination—method matters. Foods 2018, 7, 5 [CrossRef]

26. Nielsen, S.S. Phenol-sulfuric acid method for total carbohydrates. In Food Analysis Laboratory Manual; Springer: Boston, MA, USA, 2010; pp. 47-53.

27. Um, J.H.; Kim, E.-A.; Lee, W.; Kang, N.; Han, E.J.; Oh, J.Y.; Park, S.Y.; Jeon, Y.-J.; Lee, S.-H.; Ahn, G. Protective effects of an enzymatic hydrolysate from Octopus ocellatus meat against hydrogen peroxide-induced oxidative stress in Chang liver cells and zebrafish embryo. In Taurine 10; Lee, D.-H., Schaffer, S.W., Park, E., Kim, H.W., Eds.; Springer: Dordrecht, The Netherlands, 2017; pp. 603-620.

28. Fernando, I.S.; Sanjeewa, K.A.; Ann, Y.-S.; Ko, C.-I.; Lee, S.-H.; Lee, W.W.; Jeon, Y.-J. Apoptotic and antiproliferative effects of Stigmast-5-en-3-ol from Dendronephthya gigantea on human leukemia HL-60 and human breast cancer MCF-7 cells. Toxicol. Vitr. 2018, 52, 297-305. [CrossRef] [PubMed]

29. Re, R.; Pellegrini, N.; Proteggente, A.; Pannala, A.; Yang, M.; Rice-Evans, C. Antioxidant activity applying an improved ABTS radical cation decolorization assay. Free Radic. Biol. Med. 1999, 26, 1231-1237. [CrossRef]

30. Nenadis, N.; Wang, L.-F.; Tsimidou, M.; Zhang, H.-Y. Estimation of scavenging activity of phenolic compounds using the ABTS ${ }^{\bullet+}$ assay. J. Agric. Food Chem. 2004, 52, 4669-4674. [CrossRef] [PubMed]

31. Kim, K.-N.; Ham, Y.M.; Moon, J.-Y.; Kim, M.-J.; Jung, Y.-H.; Jeon, Y.-J.; Lee, N.H.; Kang, N.; Yang, H.-M.; Kim, D. Acanthoic acid induces cell apoptosis through activation of the p38 MAPK pathway in HL-60 human promyelocytic leukaemia. Food Chem. 2012, 135, 2112-2117. [CrossRef] [PubMed]

32. Han, E.-J.; Fernando, I.P.S.; Kim, H.-S.; Lee, D.-S.; Kim, A.; Je, J.-G.; Seo, M.-J.; Jee, Y.-H.; Jeon, Y.-J.; Kim, S.-Y.; et al. (-)-Loliolide Isolated from Sargassum horneri Suppressed Oxidative Stress and Inflammation by Activating Nrf2/HO-1 Signaling in IFN- $\gamma /$ TNF- $\alpha-$ Stimulated HaCaT Keratinocytes. Antioxidants 2021, 10, 856. [CrossRef]

33. Kim, D.S.; Choi, M.H.; Shin, H.J. Extracts of Moringa oleifera leaves from different cultivation regions show both antioxidant and antiobesity activities. J. Food Biochem. 2020, 44, e13282. [CrossRef]

34. Sreelatha, S.; Padma, P. Antioxidant activity and total phenolic content of Moringa oleifera leaves in two stages of maturity. Plant Foods Hum. Nutr. 2009, 64, 303-311. [CrossRef]

35. Uddin, R.; Saha, M.R.; Subhan, N.; Hossain, H.; Jahan, I.A.; Akter, R.; Alam, A. HPLC-analysis of polyphenolic compounds in Gardenia jasminoides and determination of antioxidant activity by using free radical scavenging assays. Adv. Pharm. Bull. 2014, 4, 273. [PubMed]

36. Stohs, S.J.; Hartman, M.J. Review of the safety and efficacy of Moringa oleifera. Phytother. Res. 2015, 29, 796-804. [CrossRef] [PubMed]

37. Pawlowska, E.; Szczepanska, J.; Koskela, A.; Kaarniranta, K.; Blasiak, J. Dietary Polyphenols in Age-Related Macular Degeneration: Protection against Oxidative Stress and Beyond. Oxid. Med. Cell. Longev. 2019, 2019, 9682318. [CrossRef] [PubMed]

38. Boo, Y.C. Can Plant Phenolic Compounds Protect the Skin from Airborne Particulate Matter? Antioxidants 2019, 8, 379. [CrossRef] [PubMed]

39. Kanner, J. Polyphenols by Generating $\mathrm{H}_{2} \mathrm{O}_{2}$, Affect Cell Redox Signaling, Inhibit PTPs and Activate Nrf2 Axis for Adaptation and Cell Surviving: In Vitro, In Vivo and Human Health. Antioxidants 2020, 9, 797. [CrossRef]

40. Pandey, K.B.; Rizvi, S.I. Plant polyphenols as dietary antioxidants in human health and disease. Oxid. Med. Cell. Longev. 2009, 2, 270-278. [CrossRef]

41. Dias, M.K.H.M.; Madusanka, D.M.D.; Han, E.J.; Kim, H.-S.; Jeon, Y.-J.; Jee, Y.; Kim, K.-N.; Lee, K.; Fernando, I.P.S.; Ahn, G. Sargassum horneri (Turner) C. Agardh ethanol extract attenuates fine dust-induced inflammatory responses and impaired skin barrier functions in HaCaT keratinocytes. J. Ethnopharmacol. 2021, 273, 114003. [CrossRef]

42. Sherma, J.; Fried, B. Handbook of Thin-Layer Chromatography; CRC Press: Boca Raton, FL, USA, 2003.

43. Miliauskas, G.; Venskutonis, P.; Van Beek, T. Screening of radical scavenging activity of some medicinal and aromatic plant extracts. Food Chem. 2004, 85, 231-237. [CrossRef]

44. Rastogi, R.P.; Singh, S.P.; Häder, D.-P.; Sinha, R.P. Detection of reactive oxygen species (ROS) by the oxidant-sensing probe $2^{\prime}$, $7^{\prime}$ dichlorodihydrofluorescein diacetate in the cyanobacterium Anabaena variabilis PCC 7937. Biochem. Biophys. Res. Commun. 2010, 397, 603-607. [CrossRef]

45. Brand-Williams, W.; Cuvelier, M.-E.; Berset, C. Use of a free radical method to evaluate antioxidant activity. LWT Food Sci. Technol. 1995, 28, 25-30. [CrossRef]

46. Thaipong, K.; Boonprakob, U.; Crosby, K.; Cisneros-Zevallos, L.; Byrne, D.H. Comparison of ABTS, DPPH, FRAP, and ORAC assays for estimating antioxidant activity from guava fruit extracts. J. Food Compost. Anal. 2006, 19, 669-675. [CrossRef]

47. Barzegar, A. Antioxidant activity of polyphenolic myricetin in vitro cell-free and cell-based systems. Mol. Biol. Res. Commun. 2016, 5, 87. [PubMed]

48. Matés, J.M.; Segura, J.A.; Alonso, F.J.; Márquez, J. Oxidative stress in apoptosis and cancer: An update. Arch. Toxicol. 2012, 86, 1649-1665. [CrossRef] [PubMed] 
49. Xiong, S.; Mu, T.; Wang, G.; Jiang, X. Mitochondria-mediated apoptosis in mammals. Protein Cell 2014, 5, 737-749. [CrossRef] [PubMed]

50. Fernando, I.P.S.; Dias, M.K.H.M.; Madusanka, D.M.D.; Han, E.J.; Kim, M.J.; Jeon, Y.-J.; Lee, K.; Cheong, S.H.; Han, Y.S.; Park, S.R. Human keratinocyte UVB-protective effects of a low molecular weight fucoidan from Sargassum horneri purified by step gradient ethanol precipitation. Antioxidants 2020, 9, 340. [CrossRef]

51. Li, R.; Jia, Z.; Zhu, H. Regulation of Nrf2 signaling. React. Oxyg. Species 2019, 8, 312. [CrossRef]

52. Fernando, I.P.S.; Dias, M.K.H.M.; Madusanka, D.M.D.; Han, E.J.; Kim, M.J.; Jeon, Y.-J.; Ahn, G. Fucoidan refined by Sargassum confusum indicate protective effects suppressing photo-oxidative stress and skin barrier perturbation in UVB-induced human keratinocytes. Int. J. Biol. Macromol. 2020, 164, 149-161. [CrossRef]

53. Erlank, H.; Elmann, A.; Kohen, R.; Kanner, J. Polyphenols activate Nrf2 in astrocytes via $\mathrm{H}_{2} \mathrm{O}_{2}$, semiquinones, and quinones. Free Radic. Biol. Med. 2011, 51, 2319-2327. [CrossRef] 